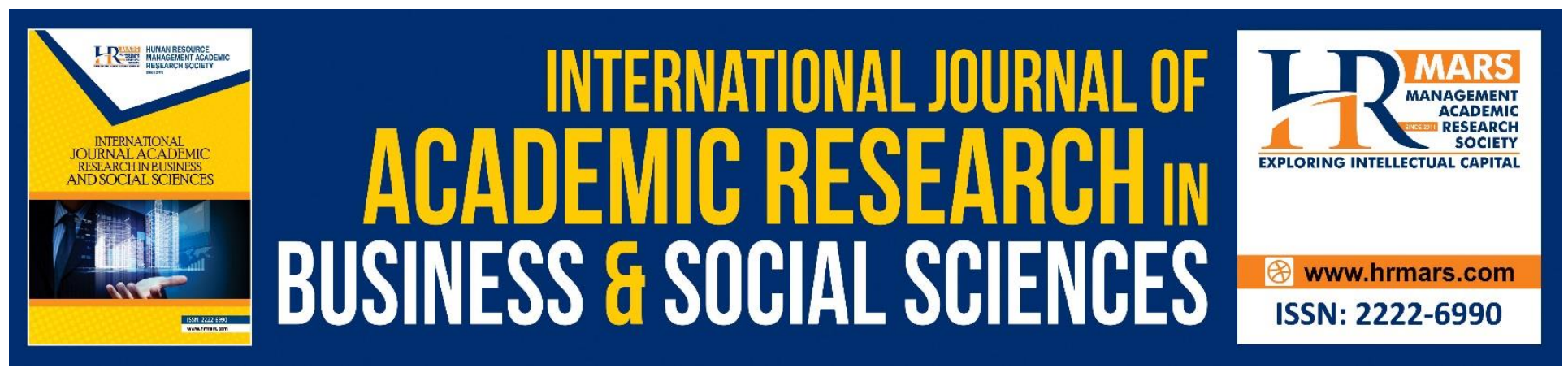

\title{
The Effect of Kodaly's Teaching Method on Preschool Children's Solfege Singing with Playing Musical Glasses Skills
}

\section{Loy Chee Luen \& Aminah Ayob}

To Link this Article: http://dx.doi.org/10.6007/IJARBSS/v9-i1/5788

DOI: $10.6007 /$ IJARBSS/v9-i1/5788

Received: 25 Dec 2018, Revised: 11 Jan 2019, Accepted: 28 Jan 2019

Published Online: 13 Feb 2019

In-Text Citation: (Luen \& Luen, 2019)

To Cite this Article: Luen, L. C., \& Luen, L. C. (2019). The Effect of Kodaly's Teaching Method on Preschool Children's Solfege Singing with Playing Musical Glasses Skills. International Journal Academic Research Business and Social Sciences, 9(1), 1257-1265.

\section{Copyright: (c) 2019 The Author(s)}

Published by Human Resource Management Academic Research Society (www.hrmars.com)

This article is published under the Creative Commons Attribution (CC BY 4.0) license. Anyone may reproduce, distribute, translate and create derivative works of this article (for both commercial and non-commercial purposes), subject to full attribution to the original publication and authors. The full terms of this license may be seen at: http://creativecommons.org/licences/by/4.0/legalcode

\section{Vol. 9, No. 1, 2019, Pg. 1257 - 1265}

Full Terms \& Conditions of access and use can be found at http://hrmars.com/index.php/pages/detail/publication-ethics 


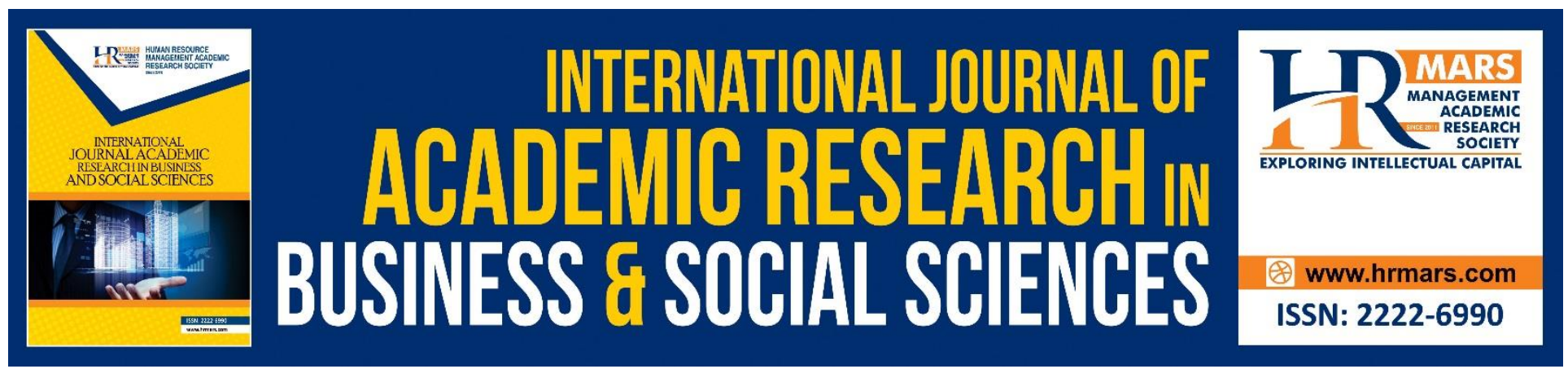

\title{
The Effect of Kodaly's Teaching Method on Preschool Children's Solfege Singing with Playing Musical Glasses Skills
}

\author{
Loy Chee Luen \& Aminah Ayob \\ Department of Early Childhood Education, \\ Faculty of Human Development, \\ Universiti Pendidikan Sultan Idris, Malaysia. \\ Colleen Wong \& Christine Augustine \\ Department of Music and Music Education, \\ Faculty of Music and Performing Arts, \\ Universiti Pendidikan Sultan Idris, Malaysia.
}

\begin{abstract}
The objective of this study was to investigate the difference between the children's solfege singing with playing musical glasses skills in terms of the diction, pitch accuracy and rhythm between the treatment group and the control group. The solfege notation selected and evaluated in this study encompasses (i) so mi and (ii) so mi la. The duration of this study is two weeks. Fifty children from two preschools were selected as the respondents in this study. This study adopts the quasiexperimental design with one treatment group and one control group of twenty five children, respectively. The treatment group sang and playing musical glasses, while the control group sang without playing musical glasses. The study finding shows that the Kodaly teaching method applying playing musical glasses is more effective to increase the skills in diction, pitch accuracy and rhythm if compared to the teaching method without playing musical glasses. Solfege singing with playing musical glasses in Kodaly teaching method has given a positive impact based on the fact that the solfege notation needs to be used to improve children's musical skills.
\end{abstract}

Keywords: Kodaly Teaching Method, Preschool, Children, Solfege Singing, Playing Musical Glasses Skills 


\section{Introduction}

Solfege singing with the playing musical glasses in the Kodaly music teaching method practiced by preschool teachers able to enhance children's musical skills. Professional musicians learn their music skills as young children close relationships with their music teachers. They spent a lot of time practicing the music instrument during early childhood (Smith, 2008). The musical activity practiced in preschool helps achieve the objective of learning of children listed in the National Preschool Standard Curriculum (2016). Integrating a Kodaly music curriculum into a developmental early childhood program can improve children's musical development and skills (Entin, 1990). Besides, early childhood educators needs to have knowledge and skills to apply the Kodaly music tea. The objective of this study is to identify the difference of children's solfege singing with playing musical glasses skills in terms of the diction, pitch accuracy and rhythm between the treatment group and the control group

\section{Literature Review}

Kodaly (1965 \& 1974) introduced solfege singing. Solfege singing can combined with hand sign, body movements and playing musical intruments for children's musical pedagogy. Since then, researchers such as Bowyer (2015) had carried out studies on the children's music pedagogy based on Kodaly's music teaching method. Study found that this method is very effective in helping and enhance children's musical skills.

Preschool teachers who practiced Kodaly music teaching method with the solfege singing syllabus that starts with so mi followed so mi la; so mi la do; so mi la do re; so $\mathrm{mi}$ la do re fa and so $\mathrm{mi}$ la do re fa ti. Teachers who teach solfege singing to children have to make an innovation in music pedagogy so that it will have an effective music teaching method for the children in preschool (Devries, 2001; Bennett, 2005; Loy, et.al 2016; 2017a; 2017b).

The study carried out by Loy, Aminah, Christine and Colleen (2016) demonstrated that children's solfege singing with playing musical glasses skills able to improve children's diction, pitch accuracy and rhythm in musical skills. Before the study is carried out, it is found that children have problems in musical skills. After the study, it is found that there is an improvement in the same set of skills. The findings for all these studies show that children's achievement in the solfege singing with playing musical glasses skills has improved after following Kodaly teaching method.

In sum, studies have proven that solfege singing with playing musical glasses skills in Kodaly teaching method can help improve children's musical skills especially diction, pitch and rhythm. Therefore, this study is implemented by applying Kodaly music teaching method to improve children's solfege singing with playing musical glasses skills. Other than that the diction, pitch accuracy and rhythm of the children are identified in this study.

\section{Methodology}

Two songs containing selected solfege notation will be used in this study. The first song has a solfege notation of so mi whereas the second song has the notation of so mi la. A check list is used to identify the children's solfege singing skills. 
INTERNATIONAL JOURNAL OF ACADEMIC RESEARCH IN BUSINESS AND SOCIAL SCIENCES

Vol. 9, No. 1, Jan, 2019, E-ISSN: 2222-6990 @ 2019 HRMARS

Song 1 (so-mi)

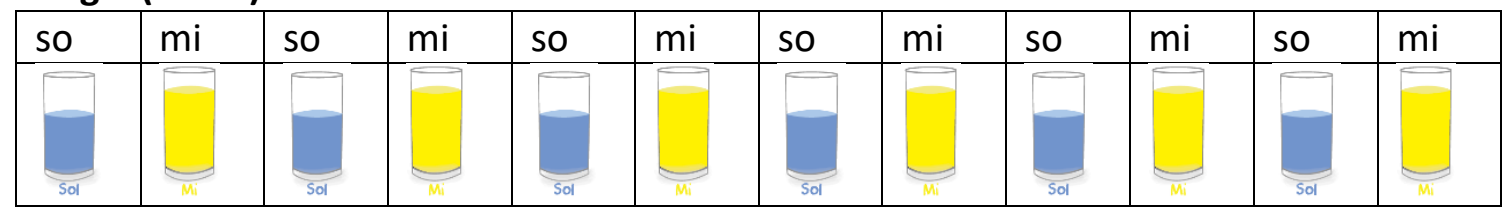

Song 2 (so-mi-la)

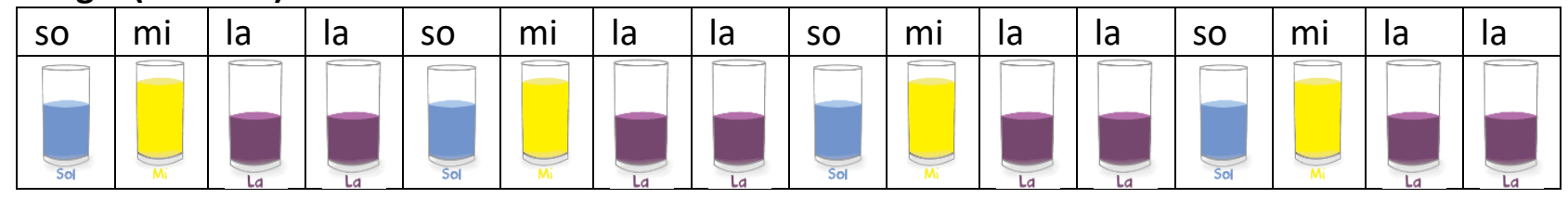

The duration of this study is two weeks. Fifty children from two preschools were selected by the respondents in this study. This study adopts the quasi-experiment design with the treatment group and control group of twenty five children, respectively. The treatment group sang with playing musical glasses, whereas the control group sang without playing musical glasses.

\section{Finding}

The study finding demonstrates that Kodaly teaching method with the musical glasses is more effective to increase the skills of diction, solfege pitch accuracy and rhythm if compared to the teaching method without the musical glasses.

1. The Skill of Solfege Singing with Musical Glasses with Notation so-mi In Terms of The Diction

\section{Table 1}

The t-test for the independent respondents concerning the solfege singing skills in terms of the diction for children taught with the solfege singing with musical glasses and solfege singing without the musical glasses.

\begin{tabular}{lllllll}
\hline $\begin{array}{l}\text { Construct } \\
\text { (Dependent } \\
\text { Variable) }\end{array}$ & $\begin{array}{l}\text { Factor } \\
\text { (Independent Variable) }\end{array}$ & N & Mean & SD & t & Sig \\
\hline \multirow{2}{*}{ Diction } & Musical glasses & 25 & 1.84 & .374 & 6.425 & .000 \\
& Without musical glasses & 25 & 1.16 & .374 & & \\
& & & & & & \\
\hline
\end{tabular}

Table 1 shows the respondents' independent t-test that was carried out to compare the solfege singing skills in terms of the diction for children taught with the solfege singing with musical glasses and solfege singing without the musical glasses. The analysis result finds that there is a difference between the solfege singing skills in terms of diction taught with and without musical glasses. 
Children taught with the musical glasses had achieved the mean of 1.84 and SD $=.374$ and children taught without the musical glasses had achieved mean 1.16 and SD $=.374$. The finding of the t-test for these independent respondents further proves that Kodaly music teaching method for solfege singing skills in terms of the diction using musical glasses is more effective if compared to the teaching without the musical glasses.

2. The Skill of Solfege Singing with Musical Glasses with Notation so-mi In Terms of Pitch Accuracy

Table 2

The t-test for the independent respondents concerning the solfege singing skills in terms of the pitch accuracy for children taught with the solfege singing with musical glasses and solfege singing without the musical glasses.

\begin{tabular}{lllllll}
\hline $\begin{array}{l}\text { Construct } \\
\begin{array}{l}\text { (Dependent } \\
\text { Variable) }\end{array}\end{array}$ & $\begin{array}{l}\text { Factor } \\
\text { (Independent Variable) }\end{array}$ & N & Mean & SD & t & Sig \\
\hline Pitch Accuracy & Musical glasses & 25 & 1.88 & .332 & 5.842 & .000 \\
& Without musical glasses & 25 & 1.24 & .436 & & \\
\hline
\end{tabular}

Table 2 shows the respondents' independent t-test that was carried out to compare the solfege singing skills in terms of the pitch accuracy for children taught with the solfege singing with musical glasses and solfege singing without the musical glasses. The result of the analysis establishes that there is a difference in the achievement of solfege singing skills in terms of the pitch accuracy between the two groups of children. Children taught with the musical glasses had achieved the mean of 1.88 and $\mathrm{SD}=.332$ and children taught without the musical glasses had achieved mean 1.24 and $\mathrm{SP}=.436$. The finding of the t-test for these independent respondents further proves that Kodaly music teaching method for solfege singing skills in terms of the pitch accuracy using musical glasses is more effective if compared to the teaching without the musical glasses.

3. The Skill of Solfege Singing with Musical Glasses with Notation so-mi In Terms of the Rhythm 
INTERNATIONAL JOURNAL OF ACADEMIC RESEARCH IN BUSINESS AND SOCIAL SCIENCES

Vol. 9, No. 1, Jan, 2019, E-ISSN: 2222-6990 (C) 2019 HRMARS

Table 3

The t-test for the independent respondents concerning the solfege singing skills in terms of the rhythm for children taught with the solfege singing with musical glasses and solfege singing without the musical glasses.

\begin{tabular}{lllllll}
\hline $\begin{array}{l}\text { Construct } \\
\text { (Dependent } \\
\text { Variable) }\end{array}$ & $\begin{array}{l}\text { Factor } \\
\text { (Independent Variable) }\end{array}$ & N & Mean & SD & t & Sig \\
\hline \multirow{3}{*}{ Rhythm } & Musical glasses & 25 & 1.96 & .200 & 7.507 & .000 \\
& Without musical glasses & 25 & 1.24 & .435 & & \\
& & & & & & \\
\hline
\end{tabular}

Table 3 shows the respondents' independent t-test carried out to compare solfege singing skills in terms of the rhythm for children taught with musical glasses and without the musical glasses. The result of the analysis establishes that there is a difference in the achievement of solfege singing skills between the two groups of children. The children taught with the musical glasses achieved the mean of 1.96 and $\mathrm{SD}=.200$ and for children taught without the musical glasses, they achieved the mean of 1.24 and $S D=.435$. The finding of the t-test concerning rhythm suggests that teaching with the musical glasses is more effective compared to teaching without the musical glasses.

4. The Skill of Solfege Singing with Musical Glasses with Notation so-mi-la In Terms of The Diction

Table 4

The t-test for the independent respondents concerning the solfege singing skills in terms of the diction for children taught with the solfege singing with musical glasses and solfege singing without the musical glasses.

\begin{tabular}{lllllll}
\hline $\begin{array}{l}\text { Construct } \\
\text { (Dependent } \\
\text { Variable) }\end{array}$ & $\begin{array}{l}\text { Factor } \\
\text { (Independent Variable) }\end{array}$ & N & Mean & SD & t & Sig \\
\hline \multirow{2}{*}{ Diction } & Musical glasses & 25 & 1.65 & .364 & 5.341 & .030 \\
& Without musical glasses & 25 & 1.40 & .351 & & \\
\hline
\end{tabular}

Table 4 shows the respondents' independent t-test that was carried out to compare the solfege singing skills in terms of the diction for children taught with the solfege singing with musical glasses and solfege singing without the musical glasses. The analysis result finds that there is a difference between the solfege singing skills in terms of diction taught with and without musical glasses. 
INTERNATIONAL JOURNAL OF ACADEMIC RESEARCH IN BUSINESS AND SOCIAL SCIENCES

Vol. 9, No. 1, Jan, 2019, E-ISSN: 2222-6990 ㄷ 2019 HRMARS

Children taught with the musical glasses had achieved the mean of 1.65 and SD $=.364$ and for children taught without the musical glasses, they achieved the mean of 1.40 and SD $=.351$. The finding of the t-test suggests that teaching with the musical glasses is more effective compared to teaching without the musical glasses, in terms of the diction.

5. The Skill of Solfege Singing with Musical Glasses with Notation so-mi-la In Terms of The Pitch Accuracy

Table 5

The t-test for the independent respondents concerning the solfege singing skills in terms of the pitch accuracy for children taught with the solfege singing with musical glasses and solfege singing without the musical glasses.

\begin{tabular}{lllllll}
\hline $\begin{array}{l}\text { Construct } \\
\begin{array}{l}\text { (Dependent } \\
\text { Variable) }\end{array}\end{array}$ & $\begin{array}{l}\text { Factor } \\
\text { (Independent Variable) }\end{array}$ & $\mathrm{N}$ & Mean & SD & t & Sig \\
\hline \multirow{2}{*}{ Pitch Accuracy } & Musical glasses & 25 & 1.64 & .490 & 2.342 & .230 \\
& Without musical glasses & 25 & 1.32 & .476 & & \\
\hline
\end{tabular}

Table 5 shows the respondents' independent t-test that was carried out to compare the solfege singing skills in terms of the pitch accuracy for children taught with the solfege singing with musical glasses and solfege singing without the musical glasses. The analysis result finds that there is a difference between the solfege singing skills in terms of diction taught with and without musical glasses. Children taught with the hand signals had achieved the mean of 1.64 and SD $=.490$ and for children taught without the musical glasses, they achieved the mean of 1.32 and SD $=.479$. The finding of the t-test suggests that teaching with the hand signals is more effective compared to teaching without the musical glasses, in terms of the pitch accuracy.

6. The Skill of Solfege Singing with Musical Glasses with Notation so-mi-la In Terms of The Rhythm 
INTERNATIONAL JOURNAL OF ACADEMIC RESEARCH IN BUSINESS AND SOCIAL SCIENCES Vol. 9, No. 1, Jan, 2019, E-ISSN: 2222-6990 ㄷ 2019 HRMARS

\section{Table 6}

The t-test for the independent respondents concerning the solfege singing skills in terms of the rhythm for children taught with the solfege singing with musical glasses and solfege singing without the musical glasses.

\begin{tabular}{lllllll}
\hline $\begin{array}{l}\text { Construct } \\
\text { (Dependent } \\
\text { Variable) }\end{array}$ & $\begin{array}{l}\text { Factor } \\
\text { (Independent Variable) }\end{array}$ & N & Mean & SD & t & Sig \\
\hline & Musical glasses & 25 & 1.87 & .329 & 4.110 & .010 \\
Rhythm & Without musical glasses & 25 & 1.39 & .500 & & \\
& & & & & & \\
\hline
\end{tabular}

Table 6 shows the respondents' independent t-test that was carried out to compare the solfege singing skills in terms of the rhythm for children taught with the solfege singing with musical glasses and solfege singing without the musical glasses. The analysis result finds that there is a difference between the solfege singing skills in terms of the rhythm, taught with and without musical glasses. Children taught with the musical glasses had achieved the mean of 1.87 and SD $=.329$ and for children taught without the musical glasses, they achieved the mean of 1.39 and SD $=.500$. The finding of the t-test suggests that teaching with the musical glasses is more effective compared to teaching without the musical glasses, in terms of the rhythm.

\section{Discussion}

In terms of the notation so-mi and so-mi-la in solfege singing, in general, it has proven that Kodaly music teaching method with the musical glasses is more effective to improve the skills of solfege singing in terms of the diction, solfege pitch accuracy and rhythm if compared to the teaching without the musical glasses.

\section{Conclusion}

All in all, the study findings show that the solfege singing with the playing musical glasses skills for both notations of so-mi and so-mi-la under the Kodaly music teaching method are more effective to improve solfege singing in terms of the diction, pitch accuracy and rhythm if compared to the teaching method without the musical glass. The findings have been consistent with Loy et.al (2016) that Kodaly music teaching method using musical glass can improve children's diction, pitch and rhythm.

\section{Acknowledgement}

The researcher would like to acknowledge the Research Management and Innovation Centre, Universiti Pendidikan Sultan Idris for the University Research Grant (2015-0148-107-01). 
INTERNATIONAL JOURNAL OF ACADEMIC RESEARCH IN BUSINESS AND SOCIAL SCIENCES

Vol. 9, No. 1, Jan, 2019, E-ISSN: 2222-6990 @ 2019 HRMARS

\section{Corresponding Author}

Dr. Loy Chee Luen

Associate Professor

Department of Early Childhood Education

Faculty of Human Development

Universiti Pendidikan Sultan Idris

Perak Malaysia

\section{References}

Bowyer, J. (2015). More than solfege and hand signs: Philosophy, tools and lesson planning in the authentic Kodaly classroom. Music Educators Journal, 102.2: 69.

Devries, P. (2001). Reevaluating common Kodaly practices. Music Educators Journal, Nov. 2001: 24.

Entin, P. (1990). Integrating a Kodaly music curriculum into a developmental early childhood program. Theses. United State: Virginia Commonwealth University.

Kementerian Pendidikan Malaysia. (2016). Kurikulum Standard Prasekolah Kebangsaan. Putrajaya: Ministry of Education Malaysia.

Kodaly, Z. (1965). Let us sing correctly. London: Boosey \& Hawkes.

Kodaly, Z. (1974). The selected writings of Zoltan Kodaly. London: Boosey \& Hawkes.

Loy, C. L., Aminah, A., Wong, C. \& Christine, A. (2016). Mencipta lagu-lagu bertema untuk menilai kemahiran nyanyian dan gerakan solfa kanak-kanak. Geran Universiti. Tanjung Malim: Universiti Pendidikan Sultan Idris.

Loy, C. L., Aminah, A., Wong, C. \& Christine, A. (2017). Kodaly's teaching method increasing preschool children's solfege singing skills. International Journal of Academic Research in Business and Social Sciences. Vol.7, No.3. 340-347.

Loy, C. L., Aminah, A., Wong, C. \& Christine, A. (2017). Kaedah Kodaly dalam pengajaran muzik kanakkanak. In Mahizer, H., Noraijni, M.N. \& Norazilawati, A. (ed). Trend dan Isu. Vol. 4. No.1. 2935.

Smith, W. (2008). Learning a music instrument in early childhood: What can we learn from profesional musician's childhood memories? Australian Journal of Early Childhood. Vol. 33. No.4. 54-6. 